Open Access

\title{
Determinants of honey producer market outlet choice in Chena District, southern Ethiopia: a multivariate probit regression analysis
}

Kassa Tarekegn ${ }^{*}$, Jema Haji ${ }^{2}$ and Bosena Tegegne ${ }^{2}$

\section{* Correspondence:} kassatar12@gmail.com

${ }^{1}$ Bonga Agricultural Research Center, Southern Agricultural Research Institute, P.O. Box 101, Bonga, Ethiopia

Full list of author information is available at the end of the article

\begin{abstract}
Marketing outlets choice is one of the most important farm household decisions to sell their produce and has a great impact on household income. Though the study area has great potential of honey production, the farmers in the study area faced the marketing problem in choice of appropriate honey market outlets. This study was therefore carried out to analyze determinants of honey producers' market outlet choice decisions in Chena district. A total of 154 honey-producing households were surveyed, and the data obtained were analyzed by using multivariate probit model. The results show that most sampled households in the study area sell their honey to cooperative outlet as compare to other outlets. The results of the econometric model show the dependency of household level marketing decisions as a strategy to maximize their incomes in the long term. The model results also reveal that the quantity of honey sold, frequency extension contact, beekeeping experience, distance to nearest market, market information about each outlet, cooperative membership, and trust in buyers determine market outlet choice decision of honey producers in the study area. Expanding equal accessibility of infrastructures, establishing honey collection centers in potential production areas, increasing the frequency of extension contact, and organizing additional beekeepers into honey cooperatives is suggested.
\end{abstract}

Keywords: Honey, Market outlets, Multivariate probit, Chena district

\section{Background}

Beekeeping is one of the oldest farming practices in Ethiopia as a result of its forests and woodlands which contain diverse plant species that provide surplus nectar and pollen to foraging bees (Workneh, 2011). The country has comparative advantage for beekeeping due to its favorable natural resource endowment for the production of honey and wax (MoA and ILRI, 2013). Ethiopia is among the major producer of honey both in Africa and in the world. For instance, in 2013, the country produced about 45,000 tons which accounted for about 27 and 3\% of African and world honey production, respectively, which makes the country the largest producer in Africa and the tenth in the world (FAOSTAT, 2015).

(c) The Author(s). 2017 Open Access This article is distributed under the terms of the Creative Commons Attribution 4.0 International License (http://creativecommons.org/licenses/by/4.0/), which permits unrestricted use, distribution, and reproduction in any medium, provided you give appropriate credit to the original author(s) and the source, provide a link to the Creative Commons license, and indicate if changes were made. 
Beekeeping is considered to be an income-generating activity that fits well with the concept of small-scale agricultural development (MoA and ILRI, 2013). Besides, it is also eco-friendly and does not compete for scarce land resources and provides off-farm employment and income-generating opportunity (Workenh, 2011). To support rural economy, agricultural production system should be supported by other income-generating activities such as beekeeping which is operated side by side (Desalegn, 2011).

Improved information and marketing facility enable farmers to plan their production more in line with market demand, to schedule their harvest at the most profitable time, to decide which market to sell their produce to, and to negotiate on a more even footing with traders (CIAT, 2004). However, current knowledge on bee product marketing is poor and inadequate for designing policies and institutions to overcome perceived problems in the marketing system (Awraris et al., 2015). According to MoA and ILRI (2013), enhancing the ability of poor smallholder farmers to reach markets and actively engaging them is one of the most pressing development challenges. Without having convenient marketing conditions, the possible increment in output, rural incomes, and foreign exchange resulting from the introduction of improved production technologies could not be effective.

Kaffa zone is highly suitable for beekeeping, and a large volume of honey is produced annually (Nuru, 2007). Kaffa zone, particularly Chena woreda, is expected to be potential for beekeeping activities associated with the high honey production by smallholder farmers in the zone. Despite high honey production, the farmers in the study area faced with the marketing problem due to remoteness of some kebeles, lack of market information, low farm-gate prices, and long market chain which results in low market participation of producers (Awraris et al., 2015).

Marketing outlet choice is one of the most important farm household decisions to sell their produce in different marketing outlets and has a great impact on household income (Shewaye, 2016). Market outlet choices are a household-specific decision, and several drivers have to be considered as a basis for such decision. Various empirical studies pointed out that smallholder farmers' decision to choose different market outlets can be affected by household characteristics, resource endowments, and access to different market outlets, prices, and transportation cost (Berhanu et al, 2013; Moti and Berihanu, 2012 and Shewaye, 2016), and they confirm that lack of market knowledge or difficulties in accessing markets that are more rewarding makes smallholder farmers to transact their produce through an outlet offering low price.

A number of studies have been done that have revealed factors influencing marketing channel choice decisions. Past empirical studies by Atsbaha (2015) and Kifle et al. (2015) attempted to identify factors affecting honey marketing channel choices among small holder producers in the Tigray Region of Ethiopia. However, there were no comprehensive earlier studies which investigated the factors affecting honey producers' market outlets' choice decision is in the southern region where there is higher amount of honey producers in Ethiopia. Thus, research in this area is vital for understanding the problems related to the honey market outlet choice decision and its determinants. Although the analysis of determinants of market outlet choices is important, there are limited empirical studies in Ethiopia, particularly on the identification of factors affecting honey producer market outlet choice decisions in southwestern parts of the country. 
Knowledge on how marketing routes will lead producers to select alternative market outlets to sell their supply that maximizes their profit which in turn results in increases of household income. The implication of these for national and international trades in apiculture is the way to design any policy or institutional innovation to improve marketing for the benefit of the poor (Kifle et al., 2015). However, the research on apiculture on the study area has largely focused on biophysical aspects such as yield enhancement, production practices, and bee disease (Awraris et al., 2015; Awraris et al., 2012; Gallmann and Thomas, 2012). Even though honey is an economically and socially important determinant of market outlets, choices have not yet been studied and analyzed for the target study area, where great potential of honey production exists. Therefore, this study attempts to investigate how the characteristics of honey producers, their resource endowment, production and marketing characteristics, and institutional service delivery jointly affect honey market outlet choice in Chena district.

\section{Methods}

\section{Description of the study area}

The study was conducted in Southern Nations and Nationalities and Peoples Region of Ethiopia, Kaffa zone, Chena district, at three kebeles. The district was purposely chosen from out of 11 districts in the zone because of its high honey-producing potential (KZLFD, 2015). The district comprises of 39 of this 36 rural kebeles and has a total population of 158,449 , of whom 78,150 are men and 80,299 women; 11,629 or $7.34 \%$ of its population are urban dwellers. The total area of Chena district is estimated to be $901.92 \mathrm{~km}^{2}$ that is endowed with natural tropical rain forests with suitable climates that favor high honeybee population density, and forest beekeeping is widely practiced.

According to CDLFO (2016), the total households found in the district are 21,685, and of these households, 7752 are honey producers. The total number of hive owned at district level from 2014 to 2016 is, in 2014, about 40,010 traditional and 4876 improved with the total of 44,886 and 43,730 traditional and 6322 improved, with the total of 50,052 in 2015, whereas in 2016, about 46,140 traditional and 7932 improved with the total of 8118 bee hives are owned by producers in the district. In this district, there are two honeyharvesting periods, April to June and September to October, of which the former is the major harvesting period contributing $95 \%$ of the annual honey production. Honey production is the main agricultural practice for most households. According to CDLFO (2016), the information from the office of livestock and fishery in the district, there are 46,140 traditional hives, 7932 improved hives, and a total of 8118 hives in 2016 (Fig. 1).

\section{Sampling techniques and sample size}

Multi-stage sampling techniques were employed for this study. Chena district was selected from Kafa zone based on its high honey production. The district actually comprises of 42 kebeles with 39 rural kebeles. At the first stage, the kebeles were stratified into honey producer (33) and non-producers (6); from these two groups of honey producers, the kebeles were selected purposively. In the second stage, from the stratified honey producer kebeles, three kebeles were selected randomly. At the third stage, total households that produce honey during 2015/16 from three randomly selected kebeles were identified and listed. Finally, based on the list of honey producers from the sampled kebeles, the intended sample 


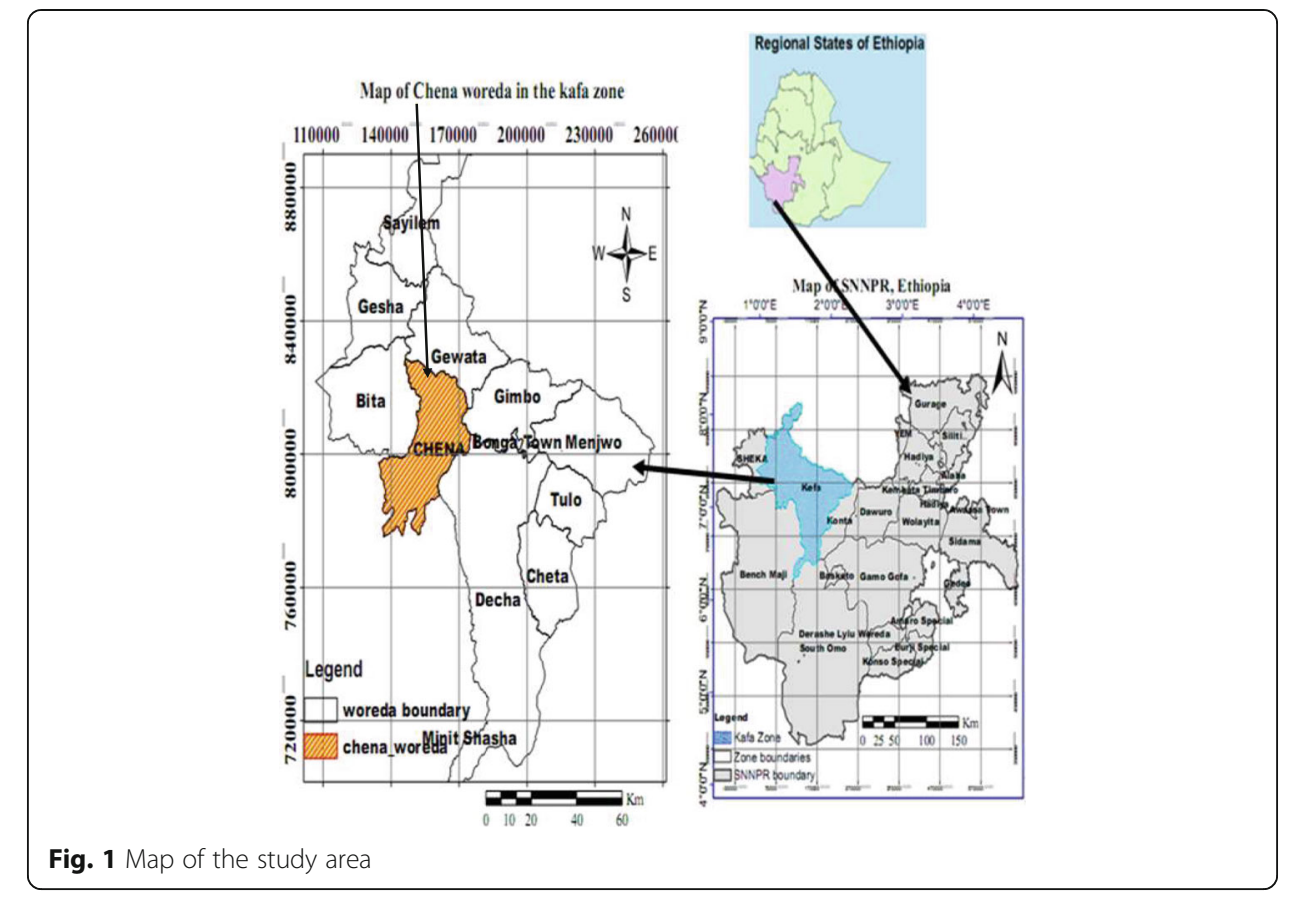

size was selected by employing probability proportional to size (PPS). Accordingly, out of 7752 honey producers in Chena district, a total of 154 sample producers are determined based on the formula given by Yamane (1967) at 95\% confidence level with degree of variability of $5 \%$ and level of precision equal to $8 \%$ :

$$
n=\frac{N}{1+N\left(e^{2}\right)}=\frac{7752}{1+7752\left(0.08^{2}\right)} \sim 154
$$

where $n$ is the sample size, $N$ is the total size of the honey producers (7752), and $e$ is the level of precision (8\%).

\section{Data types, sources, and methods of data collection}

Both primary and secondary data were used for this study. Primary data were collected using structured questionnaire for honey producers and the other for honey traders. Primary data that were collected from beekeepers focused on factors affecting market outlet choices, marketing channels, and demographic and socioeconomic characteristics of the households. Enumerators who are working in the district rural kebeles as development agents and technical assistants from Bonga Agricultural Research Center were selected. Before data collection, the enumerators were trained on the techniques of data collection and the questionnaire was pre-tested on ten households to evaluate the appropriateness of the design, clarity, and interpretation of the questions, relevance of the questions, and time taken for an interview. Hence, appropriate modifications were made on the questionnaire prior to conducting the survey. In addition to the questionnaire, an informal survey in the form of focus group discussion and key informants' interview was employed using checklists to obtain additional supporting information for the study. Secondary data were collected from different published and unpublished sources, government institutions, and websites. 


\section{Econometric model to analyze the determinants of market outlet choice}

The producers' market outlet choice can be conceptualized using a random utility model (RUM). The model is particularly appropriate for modeling discrete choice decisions such as market outlet choices. It is an indirect utility function where an individual with specific characteristics associates an average utility level with each alternative outlet in a choice set. The base for market outlet choice is the theory of rational choice which assumes that farmers are rational and will rank alternative marketing outlet for utility maximization. The choice of the marketing outlet was based on farmers' socio-economic characteristics and relevant factors influencing the choice entrenched in each outlet.

A farmer's marketing outlet choice was conceptualized using the random utility model (RUM). RUM is particularly appropriate for modeling discrete choice decisions such as between marketing outlets because it is an indirect utility function where an individual with specific characteristics associates an average utility level with each alternative marketing channel in a choice set. The honey producers were mapped into four marketing outlets: sales to collector, consumer, cooperative, and retailer. The honeyproducing farmer $i$ was able to choose from a set of alternatives $(j=1,2,3$, and 4 ) which provided a certain level of utility $U_{i j}$ from each alternative. This model was based on the principle that the farmer will choose the outlets that will maximize his/her utility. The farmer will make a comparison on marginal benefit and cost based on the utility that will be gained by selling to a combination of market outlets which will maximize its utility). However, it is not possible to directly observe the utilities but the choice made by the farmer revealed which marketing outlet provides the greater utility (Greene, 2012; Djalalou et al., 2015). Hence, the utility was decomposed into deterministic $\left(V_{i j}\right)$ and random $\left(\varepsilon_{i j}\right)$ part:

$$
U_{i j}=V_{i j}+\varepsilon_{i j}
$$

Since it was not possible to observe $\varepsilon_{i j}$ and predict exactly the choice of marketing outlet, the probability of any particular outlet choice was used in which a farmer selected a marketing outlet $j=1$ if:

$$
U i k>U i \forall_{\mathrm{j}} \neq \mathrm{k}
$$

Where $U_{i k}$ represents a random utility associated with the market channel $j=k, V_{i j}$ represents an index function denoting the decision-makers' average utility associated with this alternative, and $\boldsymbol{\varepsilon}_{i j}$ represents the random error.

As honey producers more likely choose two or more than two types of outlets simultaneously in the study area, assuming the selection of different marketing outlets, as well as their simultaneous use, depends on producers' willingness to maximize their profit and is conditional to socioeconomic, institutional, production, and market-related factors (Arinloye et al., 2014; Addisu, 2016; Shewaye, 2016). Following the literature, the researchers concluded that a producers' decision to sell in an advantageous market derives from the maximization of profit he or she expects to gain from these markets.

Econometric models such as multivariate probit/logit, multinomial probit/logit, conditional or mixed, or nested logit are useful models for analysis of categorical choicedependent variables. A number of studies have been done that have revealed factors influencing marketing channel choice decisions. A study by Bongiwe and Micah (2013), Atsbaha 
(2015), Bezabih et al. (2015) and Kifle et al. (2015) used multinomial logit model in an attempt to determine factors affecting producers' market outlet choice. Whereas Djalalou et al. (2015), Addisu (2016), and Shewaye (2016) employed multivariate probit model to analyze factors affecting producers' market outlet choice.

Multinomial models are appropriate when individuals can choose only one outcome from among the set of mutually exclusive, collectively exhaustive alternatives. However, in this study, producers' market outlet choice are not mutually exclusive, considering the possibility of simultaneous choices of outlets and the potential correlations among these market outlet choice decisions. Therefore, based on the empirical studies reviewed, multivariate probit model was adopted for this study to estimate several correlated binary outcomes jointly because it simultaneously capture the influence of the set of explanatory variables on each of the different outlet choices, while allowing for the potential correlations between unobserved disturbances, as well as the relationships between the choices of different market outlets (Greene, 2012).

The household decision of whether or not to choose is considered under the general frame work of utility or profit maximization (Djalalou et al., 2015).It is assumed that given producer $i$ in making a decision considering not exclusive alternatives that constituted the choice set $K^{\text {th }}$ of honey marketing outlets, the choice sets may differ according to the decision maker. Consider the $i$ th farm household $(i=1,2 \ldots \ldots . N)$ facing a decision problem on whether or not to choose available market outlets. Let $U_{\mathrm{k}}$ represent the benefit of farmer to choose the $K$ th market outlet: where $K$ denotes the choice of retailers $\left(Y_{1}\right)$, cooperatives $\left(Y_{2}\right)$, collectors $\left(Y_{3}\right)$, and consumers $\left(Y_{4}\right)$. The farmer decides to choose the $K^{\text {th }}$ market outlets if $Y_{i k}^{*}=U_{k}^{*}-U_{0}>0$. The net benefit $\left(Y_{i k}^{*}\right)$ that the farmer derives from choosing a market outlet is a latent variable determined by observed explanatory variable $\left(X_{\mathrm{i}}\right)$ and the error term $\left(\varepsilon_{i}\right)$ :

$$
Y^{*}{ }_{i k}=X^{\prime}{ }_{i} \beta_{k}+\varepsilon_{i} \quad\left(k=Y_{1}, Y_{2}, Y_{3}, Y_{4}\right)
$$

Thus, the econometric approach for this study is by using the indicator function; the unobserved preferences in Eq. (4) translate into the observed binary outcome equation for each choice as follows

$$
Y_{i k}=\left\{\begin{array}{l}
1 \text { if } Y^{*}{ }_{i k}>0 \\
0 \text { Otherwise }
\end{array} \quad\left(K=Y_{1}, Y_{2}, Y_{3}, Y_{4}\right)\right.
$$

In multivariate model, where the choice of several market outlets is possible, the error terms jointly follow a multivariate normal distribution (MVN) with zero conditional mean and variance normalized to unity (for identification of the parameters) where $\left(\mu_{x 1}, \mu_{x 2}, \mu_{x 3}, \mu_{x 4}\right) \mathrm{MVN} \sim(0, \Omega)$ and the symmetric covariance matrix $\Omega$ is given by:

$$
\Omega=\left[\begin{array}{lllc}
1 & \rho_{x 1 x 2} & \rho_{x 1 x 3} & \rho_{x 1 x 4} \\
\rho x 2 x 1 & 1 & \rho_{x 2 x 3} & \rho_{x 2 y 4} \\
\rho_{x 3 x 1} & \rho_{x 3 x 2} & 1 & \rho_{x 3 x 4} \\
\rho_{x 4 x 1} & \rho_{x 4 x 2} & \rho_{x 4 x 3} & 1
\end{array}\right]
$$

Of particular interest are the off-diagonal elements in the covariance matrix, which represent the unobserved correlation between the stochastic components of the different types of outlets. This assumption means that Eq. (6) generates a MVP model that 
jointly represents decision to choice particular market outlet. This specification with non-zero off-diagonal elements allows for correlation across error terms of several latent equations, which represents unobserved characteristics that affect the choice of alternative outlets.

Following the formula used by Cappellarri and Jenkins (2003), the log-likelihood function associated with a sample outcome is then given by:

$$
\ln L=\sum_{i=1}^{N} \omega_{i} \ln \Phi\left(\mu_{i}, \Omega\right) .
$$

Where $\omega$ is an optional weight for observation $i$ and $\Phi_{i}$ is the multivariate standard normal distribution with arguments $\mu_{i}$ and $\Omega$, where $\mu_{i}$ can be denoted as:

$$
\begin{aligned}
& \mu_{i}=\left(k_{i 1} \beta_{1} X_{i 1}, k_{i 2} \beta_{2}, k_{i 3} \beta_{3} x_{i 3}\right), \text { While } \Omega_{i k}=1 \text { for } j=k \text { and } \\
& \Omega_{j k}=\Omega_{k j}=k_{i j} k_{i k} \rho_{j k} \text { for } j \neq k, k=1,2,3 \ldots \ldots \text { with } k_{i k}=2 y_{i k}-1
\end{aligned}
$$

\section{Hypothesized variables}

The potential variables, which were supposed to influence producers' market outlet choice, need to be explained. Hence, the explanatory variables expected to have influence-dependent variable are summarized as follows (Table 1):

\section{Results and discussion}

\section{Characteristics of the sampled respondents}

From a total 154 sample household heads interviewed, $79.87 \%$ were male-headed households while $20.13 \%$ were female-headed households. Regarding to household size, the mean household size of the total sample households was 6.15 with maximum and minimum of 15 and 2 persons (Table 2). Concerning their literacy level, the mean edu-

\begin{tabular}{|c|c|c|c|}
\hline \multicolumn{2}{|l|}{ Variable } & Type & Expected sign \\
\hline \multicolumn{4}{|c|}{ Dependent variables } \\
\hline \multicolumn{2}{|c|}{ Honey market outlets' choice decisions } & $\begin{array}{l}1 \text { If producer choice retailers } \\
2 \text { If producer choice cooperative } \\
3 \text { If producer choice collectors } \\
4 \text { If producer choice consumers }\end{array}$ & \\
\hline \multicolumn{4}{|c|}{ Independent variables } \\
\hline HHSZ & Household size in number of families & Continuous & - \\
\hline EDLH & Education level in number of class attended & Continuous & + \\
\hline DISM & Distance to market in kilometers & Continuous & - \\
\hline $\mathrm{MIA}$ & Market information about each outlets & Dummy, $0=$ no $1=$ yes & + \\
\hline EXT & Extension service in number of contact & Continuous & + \\
\hline $\mathrm{Al}$ & Annually income in ETB & Continuous & + \\
\hline BKEX & Beekeeping experience in years & Continuous & + \\
\hline $\mathrm{VHS}$ & Honey supplied to market in kilograms & Continuous & + \\
\hline MCOP & Household membership in a cooperative & Dummy, $0=$ no $1=$ yes & + \\
\hline TRUST & Trust in buyers & Dummy $1=$ trust $0=$ not trust & + \\
\hline
\end{tabular}
cational level of sample respondents was 5.4. The farmers of the study area practice

Table 1 Summary of hypothesized variable that determines honey producers' market outlet choices 
Table 2 Summary statistics of variables

\begin{tabular}{llll}
\hline Continuous variables & Observations & Mean & Std. Dev. \\
Level of education & 154 & 5.40 & 2.63 \\
Household size & 154 & 6.15 & 2.53 \\
Total income household in 1000 & 154 & 14.52 & 4.16 \\
Years of experience in beekeeping & 154 & 12.97 & 7.95 \\
Number of hives owned currently & 154 & 19.25 & 7.02 \\
Quantity of honey sold in 2016 & 154 & 129.09 & 64.16 \\
Distance to nearest honey market & 154 & 2.65 & 1.05 \\
Frequency of extension contact per month & 154 & 2.14 & 1.06 \\
Dummy and categorical variables & & & \\
Sex & Responses & Frequency & Percentage \\
Type of beehives used & Female & 31 & 20.13 \\
& Male & 123 & 79.87 \\
Market information access & Traditional & 75 & 48.7 \\
Cooperative membership & Improved & 36 & 23.38 \\
& Both & 43 & 27.92 \\
\hline
\end{tabular}

various livelihood and income-generating activities with an average annual income of 14,520 birr per year.

On average, the sample respondents have kept honeybee for 13 years in the district. With regard to the respondents' number of hive possession, the average holding was about 19 hives per household. According to the survey result, $48.7 \%$ of the respondents were using only traditional types of hives and keeping bees in the forest by hanging the hive on long trees in dense forests and $23.9 \%$ uses only improved beehives. While, the rest $27.4 \%$ of sample beekeepers are using both traditional and improved beehives in the district. The survey result also shows that the average market supply of honey per households was $129.09 \mathrm{~kg}$ in the study area.

Table 2 depicts that out of the total honey-producing sampled households, about $94.16 \%$ of the farmers reported that they had access to extension service in 2016 production season with 2.2 times average number of extension contact per month. The survey result indicated as majority (77.92\%) of the respondents was members of honey cooperatives while the rest $(22.08 \%)$ of them was not been a member of honey production and marketing cooperatives. Finally, the average distance needed for producers to reach to nearest market place was $2.65 \mathrm{~km}$.

\section{Honey marketing outlets}

The sampled households were asked if they choose different honey market outlets to maximize the profit from their outlet choice decision. Accordingly, they reported that different honey market outlets were used to sale their honey produced. These honey market outlets include retailers, cooperatives, collectors, and consumers. These outlets 
Table 3 Description of honey market outlets

\begin{tabular}{|c|c|c|c|c|c|c|c|c|}
\hline \multirow[t]{3}{*}{ Decision } & \multicolumn{8}{|c|}{ Honey marketing outlets } \\
\hline & \multicolumn{2}{|l|}{ Retailers } & \multicolumn{2}{|c|}{ Cooperatives } & \multicolumn{2}{|l|}{ Collectors } & \multicolumn{2}{|l|}{ Consumers } \\
\hline & Frequency & $\%$ & Frequency & $\%$ & Frequency & $\%$ & Frequency & $\%$ \\
\hline Yes & 106 & 68.83 & 113 & 73.37 & 95 & 61.69 & 72 & 46.75 \\
\hline No & 48 & 31.17 & 41 & 26.63 & 59 & 38.31 & 82 & 53.25 \\
\hline \multirow[t]{2}{*}{ Supply to each outlet } & Mean & SD & Mean & SD & Mean & SD & Mean & SD \\
\hline & 47.94 & 21.46 & 87.09 & 30.40 & 60.18 & 26.87 & 33.9 & 15.78 \\
\hline
\end{tabular}

are mostly chosen in combination with one another. Table 3 shows the different honey market outlets used by the beekeepers when selling their honey. One of the most commonly used market outlets by producers is the cooperative outlet which was chosen by about $73.37 \%$ respondents with mean supply of $87.1 \mathrm{~kg}$, while about $68.83 \%$ of respondents sold to retailers with mean supply of $47.94 \mathrm{~kg}$. As collectors are also a common honey marketing outlet in the study area, around $61.69 \%$ of sample households sold to the collectors with mean supply of $60 \mathrm{~kg}$. From the total sampled households, 46.75\% of them choose consumers as honey marketing outlet with mean supply of $15.78 \mathrm{~kg}$.

\section{Determinants of honey producers market outlet choices}

The Wald test $\left.\left(\chi^{2}(48)=113.61, p=0.000\right)\right)$ is significant at the $1 \%$ level, which indicates that the subset of coefficients of the model is jointly significant and that the explanatory power of the factors included in the model is satisfactory; thus, the MVP model fits the data reasonably well. Likewise, the model is significant because the null that choice decision of the four honey market outlets is independent was rejected at $1 \%$ significance level. The results of the likelihood ratio test in the model $\left(\operatorname{LR} \chi^{2}(6)=33.52\right.$, $\left.\chi^{2}>p=0.0000\right)$ indicates the null that the independence between market outlet choice decision $\left(\rho_{21}=\rho_{31}=\rho_{41}=\rho_{32}=\rho_{42}=\rho_{43}=0\right)$ is rejected at $1 \%$ significance level and there are significant joint correlations for two estimated coefficients across the equations in the models. This verifies that separate estimation of choice decision of these outlets is biased, and the decisions to choose the four honey marketing outlets are interdependent household decisions.

There are differences in market outlet selection behavior among producers, which are reflected in the likelihood ratio statistics of estimated correlation matrix. Separately considered, the $\rho$ values $\left(\rho_{\mathrm{ij}}\right)$ indicate the degree of correlation between each pair of dependent variables. The $\rho_{41}$ (correlation between the choice for retailer and consumer outlet), $\rho_{32}$ (correlation between the choice for cooperative and collector outlet), and $\rho_{42}$ (correlation between the choice for cooperative and consumer collector outlet) are negatively interdependent and significant at the 1,10 , and $1 \%$ probability levels. This finding leads us to the conclusion that beekeeper delivering to the retailer outlet are less likely to deliver to consumer $\left(\rho_{41}\right)$. Equally, those involved in cooperative market outlet are less likely to send their honey to the collectors' and consumer outlets $\left(\rho_{32}\right.$, $\rho_{42}$ ).This indicates a competitive relationship of retailer with consumer outlet and cooperative outlet with collector and consumer outlets (Table 4).

The simulated maximum likelihood (SML) estimation result shows that the probability that honey producers choose retailer, cooperative, collector, and consumer market 
Table 4 Overall fitness, probabilities, and correlation matrix of the market outlets from the MVP model

\begin{tabular}{|c|c|c|c|c|}
\hline Variable & Retailer & Cooperative & Collector & Consumer \\
\hline Predicted probability & 0.6703 & 0.7447 & 0.6072 & 0.46791 \\
\hline Joint probability (success) & 0.1096 & & & \\
\hline Joint probability (failure) & 0.000054 & & & \\
\hline \multicolumn{5}{|l|}{ Estimated correlation matrix } \\
\hline & $\rho_{1}$ & $\rho_{2}$ & $\rho_{3}$ & $\rho_{4}$ \\
\hline$\rho_{1}$ & 1 & & & \\
\hline$\rho_{2}$ & $-0.243(0.189)$ & & & \\
\hline$\rho_{3}$ & $-0.19(0.176)$ & $-0.269^{*}(0.162)$ & & \\
\hline$\rho_{4}$ & $-0.38^{* * *}(0.133)$ & $-0.52^{* * *}(0.14)$ & $-0.11(0.155)$ & 1 \\
\hline \multicolumn{5}{|c|}{$\begin{array}{l}\text { Likelihood ratio test of: } \rho_{21}=\rho_{31}=\rho_{41}=\rho_{32}=\rho_{42}=\rho_{43}=0: \\
x^{2}(6)=33.52 \\
\text { Prob }>x^{2}=0.0000^{* * *}\end{array}$} \\
\hline Number of draws (\#) & 15 & & & \\
\hline Number of observations & 154 & & & \\
\hline Log likelihood & -264.77 & & & \\
\hline Wald $\left(X^{2}(48)\right)$ & 113.61 & & & \\
\hline Prob $>x^{2}$ & $0.0000^{* * *}$ & & & \\
\hline
\end{tabular}

outlets were $67.03,74.5,60.7$, and $46.73 \%$, respectively. This indicates the likelihood of choosing consumer outlet is relatively low $(46.79 \%)$ as compared to the probability of choosing retailer (67.03\%), cooperative (74.5\%), and collector $(60.7 \%)$. The joint probabilities of success or failure of the four outlet choice also suggest that households are more likely to success to jointly choose the four outlets. The likelihood of households to jointly choose the four outlets simultaneously is $10.96 \%$, while their failure to jointly choose is nearly null.

Based on result of MVP model in Table 5, some of the variables were significant at more than one market outlet while one variable was significant in only one market outlet. Out of ten explanatory variables included in the model, three variables affected significantly retailer market outlet; five variables significantly affected cooperative outlet; four variables significantly affected collector outlet; and two variables significantly affected consumer market outlet choice at different probability levels.

Beekeeping experience has a positive relationship with likelihood of choosing cooperative outlet at 5\% levels of significance. The result showed that those households with a more number of year engagement in honey production and marketing are more likely to choose cooperatives outlet. This may be due to that experienced beekeepers had better knowledge of cost and benefits associated with various honey marketing outlets that give the producers desire to adjust their market links, trying alternative marketing outlets to increase sales volume so as to increase the profits. Consequently, the likelihood of choosing it is high as the result of experience favor to choose cooperative outlet. The finding of Kifle et al. (2015) showed that the number of years a household spent in beekeeping positively and significantly affected using cooperative market outlet.

The volume of honey supply to market influences positively the likelihood of choosing cooperative market outlet at 5\% significance level and influenced negatively 
Table 5 Multivariate probit estimations for determinants of producers' outlet choice

\begin{tabular}{lllll}
\hline Variables & Market outlets & & \\
\cline { 2 - 4 } & $\begin{array}{l}\text { Retailers } \\
\text { Coeff(Se) }\end{array}$ & $\begin{array}{l}\text { Cooperatives } \\
\text { Coeff(Se) }\end{array}$ & $\begin{array}{l}\text { Collectors } \\
\text { Coeff(Se) }\end{array}$ & $\begin{array}{l}\text { Consumers } \\
\text { Coeff(Se) }\end{array}$ \\
\hline Education level & $0.0008(0.063)$ & $0.054(0.082)$ & $-0.039(0.072)$ & $0.073(0.035)$ \\
Household size & $0.021(0.057)$ & $0.053(0.079)$ & $0.038(0.066)$ & $0.064(0.057)$ \\
Total income & $-0.002(0.003)$ & $0.0014(0.0036)$ & $0.003(0.004)$ & $-0.002(0.003)$ \\
Experience & $-0.028(0.048)$ & $0.125^{* *}(0.062)$ & $0.0356(0.054)$ & $-0.067(0.052)$ \\
Volume supplied & $-0.002(0.0017)$ & $0.007^{* *}(0.003)$ & $0.0057(0.0038)$ & $-0.005^{* * *}(0.002)$ \\
Extension contact & $0.320^{* *}(0.156)$ & $0.516^{* *}(0.203)$ & $-0.06(0.142)$ & $0.25(0.163)$ \\
Distance to market & $-0.216^{*}(0.120)$ & $0.352^{*}(0.181)$ & $0.13^{* * *}(0.041)$ & $0.05(0.121)$ \\
Trust of buyer & $-0.194(0.250)$ & $0.387(0.318)$ & $0.94^{* * *}(0.290)$ & $0.19(0.232)$ \\
Market information & $0.04^{* * *}(0.014)$ & $0.015(0.013)$ & $-0.049^{*}(0.024)$ & $0.039^{*}(0.020)$ \\
Coop. membership & $-0.019(0.340)$ & $1.17^{* *}(0.420)$ & $-0.95^{* *}(0.470)$ & $-0.456(0.38)$ \\
Constant & $1.980(1.482)$ & $-1.55^{* *}(0.720)$ & $1.368^{*}(0.804)$ & $1.81(1.331)$ \\
\hline
\end{tabular}

$*, * *$, and ${ }^{* * *}=$ significance level at 10,5 , and $1 \%$, respectively

Coeff coefficient, Se standard errors in parentheses

the likelihood of choosing consumer outlet at $1 \%$ level of significance. This result indicated that those households with large volume of honey were more likely to sell to cooperative. This is because the cooperative has the capacity to purchase large quantity of honey and beekeepers' expectations of future benefits like share dividend for those households who supply more honey. The implication is that if the quantity of honey to be sold is large, beekeepers search market outlets that buy large volume with reasonable price and incentive. This finding is in line with the results of Muthini (2015). Moreover, the negative influence of variable with likelihood of choosing consumer outlets was due the preference of other market outlets that purchase in large quantity. This implies that if the quantity to be sold is low, beekeepers are not forced to search incentives from other outlets. This result is consistent with study by Atsbaha (2015).

Distance from the market is negatively associated with likelihood of producers selling to retailer $10 \%$ level of significance and positively associated with likelihood selling to cooperative and collector outlets at 10 and $1 \%$ level of significance, respectively. It reflects that household located far away from the nearest market center faces difficulty in delivering honey to retailer outlet due to poor road facility to sell their product. Hence, they sold to available market outlets in their locality. As a result, supplying honey to retailers requires transporting the product to urban market to meet retailers. This is in line with the finding of Atsbaha (2015) that showed distance to nearest market was negatively and significantly related to the channel choice of retailers' channel.

Moreover, the positive relation of distance and likelihood of choosing a cooperative and collector was due to the fact that cooperatives have honey collection centers in each kebeles/nearby kebeles to collect honey at farm gate that reduces the transportation cost of beekeepers. Likewise, collectors purchase honey at farm gate from beekeepers by going door to door during the harvesting season. This implied that with the increase in distance to market, beekeepers preferred to sell to honey cooperatives in their kebeles or in nearby kebeles and collectors, rather than selling to other market outlets that associated with incurring higher transportation costs. This result is similar to the finding of Bardhan et al. (2012). 
Frequency of extension contact has a positive and significant influence on retailer and cooperative outlet choice decision at 5\% significance level. Extension services increase the ability of farmers to acquire important market information as well as enable the beekeepers to improve production methods, hence leading to more output which in turn increases producers' ability to choose the best market outlet for their product. Thus, households who were visited more by extension agents were more likely to deliver honey via retailer and cooperative outlets. This result is similar to a study by Bardhan et al. (2012) that confirms regular contact with extension functionaries had a positive influence on the likelihood choice of cooperative outlet by milk producer in Uttarakhand.

Trust in buyers is positively and significantly associated with choice of collector outlet at $1 \%$ significance level. The positive and significant result showed that households who trust in buyers are more likely to deliver honey to collector outlet. A good reputation and trustworthiness of traders increase producers' commitment to collector because it reduces opportunistic behavior and promotes cooperation and commitment in the relationship. This study is in line with Addisu (2016) who found trust in buyer is associated positively with collector outlet that farmers who trust in traders are more likely to choose rural collectors to sell their onion product.

Access to market information is also positively and significantly associated with the likelihood of choosing retailer and consumer outlets at 1and $10 \%$ level of significance, respectively. Access to current market information improves producers' selling price, because market information helps producers to analyze the price difference in their locality and the nearby main market that increases probability of choosing retailers and consumers which give relatively higher price to producers. The findings of Bezabih et al. (2015) confirmed that market information has a positive and significant effect on retailer channel choice decision of potato producers. Moreover, the variable is negatively significantly associated with the choice of collector outlet at $1 \%$ significance level. The negative relation may be due to preference of other outlets that give relatively higher price. This declines beekeepers' preference to local collectors; rather, they transport it to the nearest market. This is in line with the finding of Astabah (2015).

Cooperative membership has a positive and significant influence on the likelihood of choosing cooperative outlet. Thus, a member of honey production and marketing cooperatives has the responsibility to supply to its cooperative from their production as a norm of cooperative even if they sell to other outlets. This may be also because the cooperative provides some technical assistance and training to its members and gives a share dividend at the end of each year. The variable is also associated negatively with collectors' outlet choice at $5 \%$ probability level of significance. The negative relation indicates that beekeepers who were members of cooperative are less likely to choose collector outlet compared to those who are not members due to incentives of cooperative. This finding is similar with the finding of Bongiwe and Micah (2013).

\section{Conclusions}

This article has analyzed the influence of the characteristics of beekeepers, their production systems, and the marketing context on their market outlets' choice decision. The literature in market outlets' choice stresses that beekeepers prefer a particular market outlet either because of its closeness or outlet that offers the best price. 
However, the results show that beekeepers use different alternative market outlets such as retailers, cooperatives, local collectors, and consumers. The results show that most sampled households in the study area sell their honey to cooperative outlet as compared to other outlets.

The results of the econometric model show that the dependency of household level marketing decisions can be empirically tested. The beekeepers select multiple marketing outlets as a strategy to safeguard their investments and to maximize their incomes in the long term. It was found that those involved in cooperative marketing are less likely to send their honey to the retailers and collectors. Even though we observed negative correlations between some choices of market outlets, these correlations are not statistically significant. This result is inconsistent with a marketing channel selection study in the Tigria Region of Ethiopia (Kifle et al., 2015) that found strong evidence to support the hypothesis that sellers make their market outlets' selection for a particular market outlet rather than simultaneously two and more.

One important result of our analysis is that honey producers who sell into retailer and rural collector were characterized mostly by low volume and quality, respectively. This is strongly related to their poor access to road and market information (about quality and prices), their low extension packages knowhow, and their weak capacity to comply with cooperative market requirements. Thus, expanding equal accessibility of infrastructures such as road and transportation facilities needs government intervention to promote the effective marketing of honey through all outlets.

A cooperative membership and his or her physical distance from markets were identified as major determinants of market outlet selection. Establishing honey collection centers in potential production areas encourage honey producers and enable them to sell their product at better a price. Further, capacitating the existing honey cooperatives and organizing additional beekeepers into honey cooperatives is also suggested as the cooperatives had the capacity to purchase large volume of honey with reasonable price, providing technical assistance and training to its members.

\section{Acknowledgements}

The authors would like to thank the sampled beekeepers and experts of livestock and fishery office of Chena district for their cooperation in providing necessary information. The financial support of Southern Agricultural Research Institute is gratefully acknowledged.

Funding

The Southern Agricultural Research Institute and Bonga Agricultural Research Center supported this research financially and logistically, respectively.

Authors' contributions

The data collection, analyzing of the data, and drafting of the manuscript was done by KT. JH and BT's primary role in the paper is the revision of the drafted manuscript and guidance on additional interpretations of the results. All authors have read and approved the final manuscript.

Competing interests

The authors declare that they have no competing interests.

\section{Publisher's Note}

Springer Nature remains neutral with regard to jurisdictional claims in published maps and institutional affiliations. 
Received: 11 February 2017 Accepted: 28 September 2017

\section{Published online: 06 October 2017}

\section{References}

Addisu H (2016) Value chain analysis of vegetables: the case of Ejere District, West Shoa Zone, Oromia National Regional State of Ethiopia. MSc. Thesis, Haramaya University, Ethiopia

Arinloye D, Pascucci S, Linnemann A, Coulibaly O, Hagelaar G, Omta O (2014) Marketing channel selection by smallholder farmers. J Food Prod Mark 00:1-21

Atsbaha M (2015) Value chain analysis of movable frame hive honey: the case of Ahferom Woreda, Tigray, Ethiopia. MSc. Thesis, Aksum University, Ethiopia

Awraris G, Yemisarach G, Degane A, Nuri A, Gebayo G, Workine A (2012) Honey production systems (Apis Mellifera L.) in Kafa, Sheka and Bench-Maji zones of Ethiopia. Journal of Agricultural Extension and Rural Development 4(19): 528-541

Awuraris G, Ammany A, Hailemariam G, Nur A, Degene A, Zeriyhuni T (2015) Comparative analysis of colony performance and profit from different beehive types in Southwest Ethiopia: global. Journal of Animal Scientific Research 3(1):178-185

Bardhana D, Sharmab ML, Saxenac R (2012) Market participation behavior of smallholder dairy farmers in Uttarakhand. Agric Econ Res Rev 25(2):243-254

Berhanu K, Derek B, Kindie G, Belay K (2013) Factors Affecting Milk Market Outlet Choices in Wolaita Zone, Ethiopia. African Journal of Agricultural Marketing 1(2):024-031

Bezabih E, Mengistu K, Jeffreyson KM, Jemal Y (2015) Factors affecting market outlet choice of potato producers in Eastern Hararghe Zone, Ethiopia. Journal of Economics and Sustainable Development 6(15):159-172

Bongiwe GX, Micah BM (2013) Factors affecting the choice of marketing channel by vegetable farmers in Swaziland. Sustainable Agriculture Research 2(1):112-123

Cappellari L, Jenkins SP (2003) Multivariate probit regression using simulated maximum likelihood. Stata J 3(3):278-297

CDLFO (Chena District Livestock and Fishery Office) (2016) Livestock extension profile of the district

CIAT (Centro International de Agricultural Tropical) (2004) Increasing the competitiveness of market chains of smallholder's producers. Manual, 3: Territorial Approach to Rural Agro Enterprise Development Project

Desalgne P (2011) Ethiopian honey: accessing international markets with inclusive business and sector development, SNV Ethiopia. Available at: file:///C:/ Users/gebruiker/ Downloads/7. _soc_ethiopia_honey\%20(23).pdf [accessed on 12 July 2016]

Djalalou-Dine AAA, Pascucci S, Linnemann AR, Coulibaly ON, Hagelaar G, Omta OSWF (2015) Marketing channel selection by smallholder farmers. J Food Prod Mark 21(4):337-357

FAOSTAT (Food and Agriculture Organization of the United Nations) (2015) FAOSTAT (database). (Latest update: 07 Mar 2014) viewed 15 Jul 2016, http://data.fao.org/ ref/262b79ca-279c-4517-93de-ee3b7c7cb553.html?version=1.0

Gallmann P and Thomas H (2012) Beekeeping and honey production in Southwestern Ethiopia: Online.http://www. learningforlife.ch/media//DIR_76001/76253729aa011222ffff8015a426365.pdf

Greene W (2012) Econometric analysis, 7th edn. Prentice Hall, Pearson, NJ

Kifle T, Tekeste B, Abadi A (2015) Determinants of the choice of marketing channel among small-scale honey producers in Tigrai Region of Ethiopia. Journal of Business Management \& Social Sciences Research 4(4):295-305

KZLFD (Kaffa Zone Livestock and Fishery Department) (2015) Livestock ExtensionProfile of the Zone

MoA and ILRI (2013) Apiculture value chain vision and strategy for Ethiopia. Addis Ababa, Ethiopia: Ministry of Agriculture and International Livestock Research Institute

Moti J, Berhanu G (2012) Interdependence of smallholders' net market positions in mixed crop-livestock systems of Ethiopian highlands. Journal of Development and Agricultural Economics 4(7):199-209

Muthini N.D (2015) An assessment of mango farmers' choice of marketing channels in Makueni, Kenya. MSc Thesis, University of Nairobi, Nairobi, Kenya

Nuru A (2007) Atlas of pollen grains of major honey bee flora of Ethiopia: Sixth National Annual Conference of the Ethiopian Beekeepers Association (EBA), Addis Ababa, Ethiopia

Shewaye A (2016) Econometric analysis of factors affecting haricot bean market outlet choices in Misrak Badawacho District, Ethiopia. International Journal of Research Studies in Agricultural Sciences 2(9):6-12

Workneh A (2011) Identification and documentation of indigenous knowledge of beekeeping practices in selected districts of Ethiopia. Journal of Agricultural Extension and Rural Development 3(5):82-87

Yamane T (1967) Statistics: an introductory analysis, 2nd edn. Harper and Row, New York 